Key Words:

DWPF, SME, MFT, pH, Rheology

Retention:

Permanent

\title{
RHEOLOGICAL AND ELEMENTAL ANALYSES OF SIMULANT SB5 SLURRY MIX EVAPORATOR-MELTER FEED TANK SLURRIES
}

\author{
A. I. Fernandez
}

FEBRUARY 2010

Savannah River National Laboratory Savannah River Nuclear Solutions

Aiken, SC 29808 


\section{DISCLAIMER}

This work was prepared under an agreement with and funded by the U.S. Government. Neither the U. S. Government or its employees, nor any of its contractors, subcontractors or their employees, makes any express or implied:

1. warranty or assumes any legal liability for the accuracy, completeness, or for the use or results of such use of any information, product, or process disclosed; or

2. representation that such use or results of such use would not infringe privately owned rights; or

3. endorsement or recommendation of any specifically identified commercial product, process, or service.

Any views and opinions of authors expressed in this work do not necessarily state or reflect those of the United States Government, or its contractors, or subcontractors.

Printed in the United States of America

Prepared for

U.S. Department of Energy 
Key Words:

DWPF, SME, MFT, pH, Rheology

Retention:

Permanent

\title{
RHEOLOGICAL AND ELEMENTAL ANALYSES OF SB5 SLURRY MIX EVAPORATOR-MELTER FEED TANK SLURRIES
}

\author{
A. I. Fernandez
}

JANUARY 2010

Savannah River National Laboratory

Savannah River Nuclear Solutions

Savannah River Site

Aiken, SC 29808 


\section{REVIEWS AND APPROVALS}

A.I. Fernandez, Author, Process Technology Programs

M.E. Stone, Peer Reviewer, Process Technology Programs

S.H. Reboul, Peer Reviewer, Process Technology Programs

C. C. Herman, Manager, Process Technology Programs

S. L. Marra, Manager,

Environmental \& Chemical Process Technology Research Programs

J. E. Occhipinti, Manager

Waste Solidification Engineering
Date

Date
Date

Date

Date

Date

- ii - 


\section{TABLE OF CONTENTS}

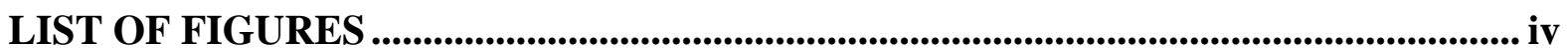

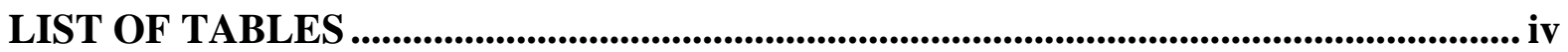

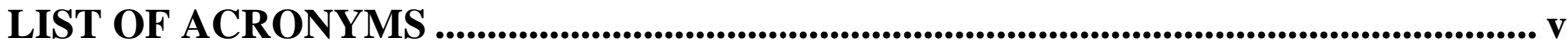

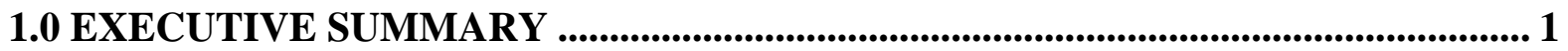

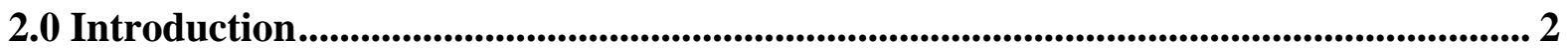

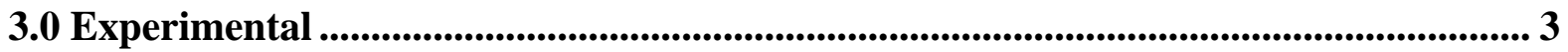

3.1 Simulant preparation ....................................................................................................... 3

3.2 Apparatus ............................................................................................................................ 3

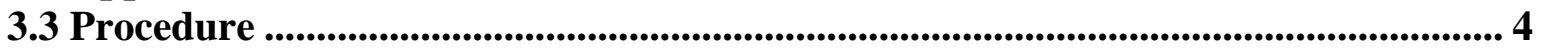

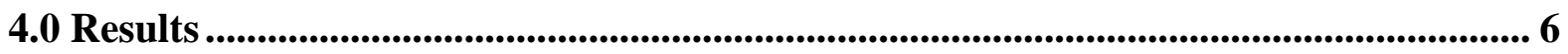

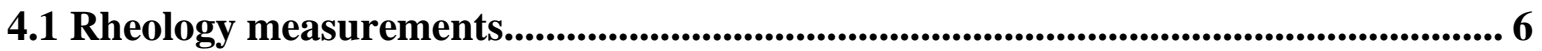

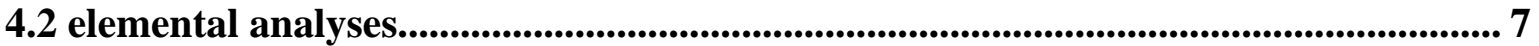

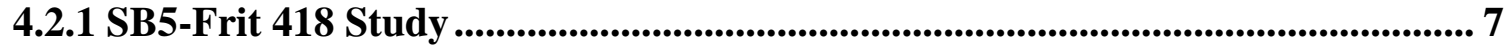

4.2.2 Frit 418-Water Blank Study .................................................................... 10

4.2.3 Comparison of Both Systems ...................................................................... 11

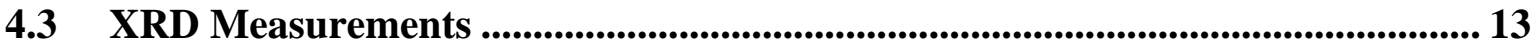

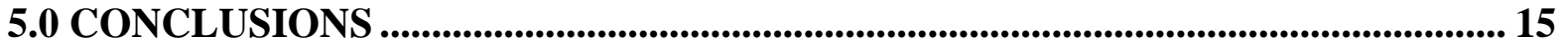

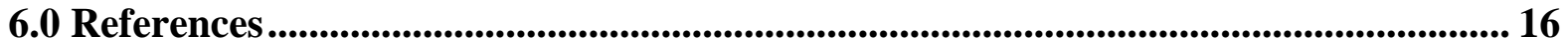

APPENDIX A. ELEMENTAL CONCENTRATIONS VERSUS TIME ...................... 18

APPENDIX B. Leaching \% VERSUS TIME (figure 7) ................................................... 19

APPENDIX C. SUPERNATE CONCENTRATIONS VERSUS TIME ......................... 20 


\section{LIST OF FIGURES}

Figure 1. Picture of low and high $\mathrm{pH}$ apparatuses ......................................................... 3

Figure 2. Rheograms of both low and high $\mathrm{pH}$ slurries after 15 hours of boiling .................. 6

Figure 3. Rheograms of both low and high $\mathrm{pH}$ slurries after 30 hours of boiling ................. 7

Figure 4. Lower limit leaching $\%$ of $\mathrm{B}, \mathrm{Li}$, and $\mathrm{Si}$ as a function of time and $\mathrm{pH}$.................. 9

Figure 5. Concentration of several elements as a function of time..................................... 10

Figure 6. Lower limit leaching $\%$ as a function of time and $\mathrm{pH}$ in Frit-water system .......... 11

Figure 7. Lower limit leaching \% of sludge (smaller symbols) and Frit-water systems ...... 12

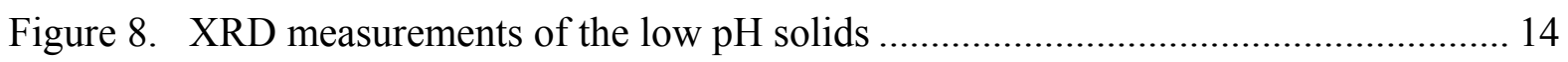

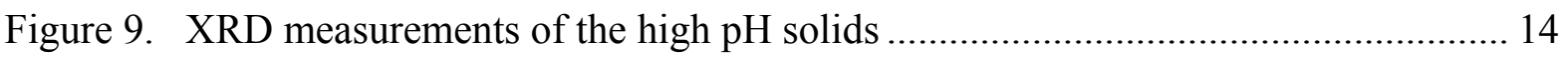

\section{LIST OF TABLES}

Table 1. Properties of Sludge Batch 5-6 (SB5-6) …………............................................ 3

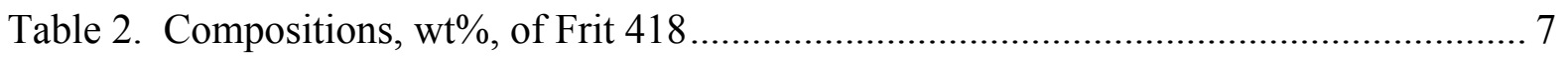

Table 3 Calculated lower limit of leaching percentages (mass) of B and Li......................... 8 


\section{LIST OF ACRONYMS}

$\begin{array}{ll}\text { ACTL } & \text { Aiken County Technology Laboratory } \\ \text { DWPF } & \text { Defense Waste Processing Facility } \\ \text { HIP } & \text { High } \mathrm{pH}(\mathrm{pH} \sim 10) \\ \text { LOP } & \text { Low } \mathrm{pH}(\mathrm{pH} \sim 7.5) \\ \text { MFT } & \text { Melter Feed Tank } \\ \text { PSAL } & \text { Process Science Analytical Laboratory } \\ \text { SB5 } & \text { Sludge Batch 5 } \\ \text { SME } & \text { Slurry Mix Evaporator } \\ \text { SRAT } & \text { Sludge Receipt and Adjustment Tank } \\ \text { SRNL } & \text { Savannah River National Laboratory } \\ \text { TTR } & \text { Technical Task Request } \\ \text { XRD } & \text { X-ray Diffraction }\end{array}$




\subsection{EXECUTIVE SUMMARY}

The Defense Waste Processing Facility (DWPF) will complete Sludge Batch 5 (SB5) processing in fiscal year 2010. DWPF has experienced multiple feed stoppages for the SB5 Melter Feed Tank (MFT) due to clogs. Melter throughput is decreased not only due to the feed stoppage, but also because dilution of the feed by addition of prime water (about 60 gallons), which is required to restart the MFT pump. SB5 conditions are different from previous batches in one respect: $\mathrm{pH}$ of the Slurry Mix Evaporator (SME) product (9 for SB5 vs. 7 for SB4). Since a higher $\mathrm{pH}$ could cause gel formation, due in part to greater leaching from the glass frit into the supernate, SRNL studies were undertaken to check this hypothesis.

The clogging issue is addressed by this simulant work, requested via a technical task request from DWPF. The experiments were conducted at Aiken County Technology Laboratory (ACTL) wherein a non-radioactive simulant consisting of SB5 Sludge Receipt and Adjustment Tank (SRAT) product simulant and frit was subjected to a 30 hour SME cycle at two different pH levels, 7.5 and 10; the boiling was completed over a period of six days. Rheology and supernate elemental composition measurements were conducted.

The caustic run exhibited foaming once, after 30 minutes of boiling. It was expected that caustic boiling would exhibit a greater leaching rate, which could cause formation of sodium aluminosilicate and would allow gel formation to increase the thickness of the simulant. Xray Diffraction (XRD) measurements of the simulant did not detect crystalline sodium aluminosilicate, a possible gel formation species. Instead, it was observed that caustic conditions, but not necessarily boiling time, induced greater thickness, but lowered the leach rate. Leaching consists of the formation of metal hydroxides from the oxides, formation of boric acid from the boron oxide, and dissolution of $\mathrm{SiO}_{2}$, the major frit component. It is likely that the observed precipitation of $\mathrm{Mg}(\mathrm{OH})_{2}$ and $\mathrm{Mn}(\mathrm{OH})_{2}$ caused the increase in yield stress. The low $\mathrm{pH}$ run exhibited as much as an order of magnitude greater $\mathrm{B}$ and $\mathrm{Li}$ (frit components) leachate concentrations in the supernate. At high $\mathrm{pH}$ a decrease of $\mathrm{B}$ leaching was found and this was attributed to adsorption onto $\operatorname{Mg}(\mathrm{OH})_{2}$. A second leaching experiment was performed without any sludge to deconvolute the leach rate behavior of Frit 418 from those of the SB5 sludge-Frit 418 system. At high $\mathrm{pH}$, the sludgeless system demonstrated very fast leaching of all the frit components, primarily due to fast dissolution of the main component, silica, by hydroxide anion; various semiconductor studies have established this reactivity. Overall, the frit-water system exhibited greater leaching from a factor two to almost three orders of magnitude (varying by conditions and species). The slower leaching of the sludge system is possibly due to a greater ionic strength or smaller driving force. Another possible reason is a physical effect, coating of the frit particles with sludge; this would increase the mass transfer resistance to leaching.

Based on this study, the cause of clogs in the melter feed loop is still unknown. A possible explanation is that the SME product, like the simulant, is too thin and could contribute to a loss of two-phase flow which could cause plugging of a restricted and poorly mixed zone like the melter feed loop. This is feasible since a previous study of a slurry showed an increase in resistance to flow at lower flow rates. Testing with a radioactive SME sample is underway and should help understand this potential mechanism. 


\subsection{INTRODUCTION}

The Defense Waste Processing Facility (DWPF) will complete Sludge Batch 5 (SB5) processing in fiscal year 2010. Recently, DWPF has noted a loss of feed to the melter feed loop due to clogs, which in turn has resulted in multiple feed stoppages to the melter. Moreover, addition of prime water (about 60 gallons) is required to restart the melter feed pump and further dilutes the feed. The stoppages and the remedial measures both cause a decrease in overall melter throughput.

In order to discover the cause of this problem, a review of available data was performed by DWPF Engineering and potential trends were examined. One difference noted was the SB5 Slurry Mix Evaporator (SME) product $\mathrm{pH}$, which is rather high (9 for SB5 vs. 7 for SB4). The $\mathrm{pH}$ of the SME slurry product can greatly influence the rheological properties, which depend in part on the partitioning of soluble and insoluble solids. Previous observations indicated that a higher $\mathrm{pH}$ can lead to gel formation ${ }^{1}$ which could in turn lead to clogging of transfer lines. A reason given for these undesirable physical and chemical changes was the greater amount of leaching from the frit at higher $\mathrm{pH}$. Thus, chemical methods used to decrease $\mathrm{pH}$ could make the pumping and transferring of SB5 SME product more efficient.

The aim of the experiment was to compare the rheological and leaching behavior of a SB5 slurry simulant (including frit) at low and high $\mathrm{pH}$ (7 and 10) during a 30 hour, boiling SME cycle. This work is based on the task plan SRNL-RP-2009-01199, which was requested via technical task request HLW-DWPF-TTR-2009-0030., ${ }^{2,3}$ The work involved the use of two one-liter rigs to perform SME cycles on two SB5 simulant (non-radioactive) slurries with differing $\mathrm{pH}$ levels, 7.5 and 10; otherwise the simulants and the procedures were identical. Rheological and composition measurements were used to determine the effect of $\mathrm{pH}$ on the likelihood of gel formation in SB5 sample slurry and to determine whether a positive correlation was observed with leach rate.

To better understand the results, a blank experiment was run to deconvolute the effects of the sludge simulant from those of leaching from the glass frit. This experiment was performed with a frit-water mixture only; no sludge simulant was used. 


\subsection{EXPERIMENTAL}

The R\&D Directions are given in documents SRNL-L3100-2009-00247 $7^{4}$ and SRNL-L31002009-302 ${ }^{5}$. Details were recorded in notebook WSRC-NB-2005-00143. The experiments were carried out at Aiken County Technology Laboratory (ACTL).

\subsection{SIMULANT PREPARATION}

SRAT product from a previous study, ${ }^{6}$ SB5-6, containing no mercury was selected due to a concern that high $\mathrm{pH}$ levels might contribute to formation of dimethylmercury, an extremely toxic substance. ${ }^{7,8}$ Offgas composition was not monitored since noble metals, known to generate hydrogen, were not present. Properties of the SB5-6 are summarized in Table 1.

Table 1. Properties of SB5-6 SRAT Product Simulant

\begin{tabular}{|c|c|c|c|}
\hline $\mathbf{p H}$ & density & Total solids \% & calcined \% \\
\hline 4.4 & 1.23 & 25.3 & 14.9 \\
\hline
\end{tabular}

\subsection{APPARATUS}

Due to the limited amount of SB5-6, two $500 \mathrm{~g}$ samples were used and these were placed in one liter vessels. A thermocouple, mechanical mixer, anti-foam addition funnel, air purge input, Friedrich condenser, and a heating mantle were installed. The air purge flow rates, both in and out, were measured with MKS flow controllers. Figure 1 shows a picture of the rigs for the low $\mathrm{pH}$ ("LOP") and high $\mathrm{pH}$ ("HIP") runs; the runs were performed concurrently.

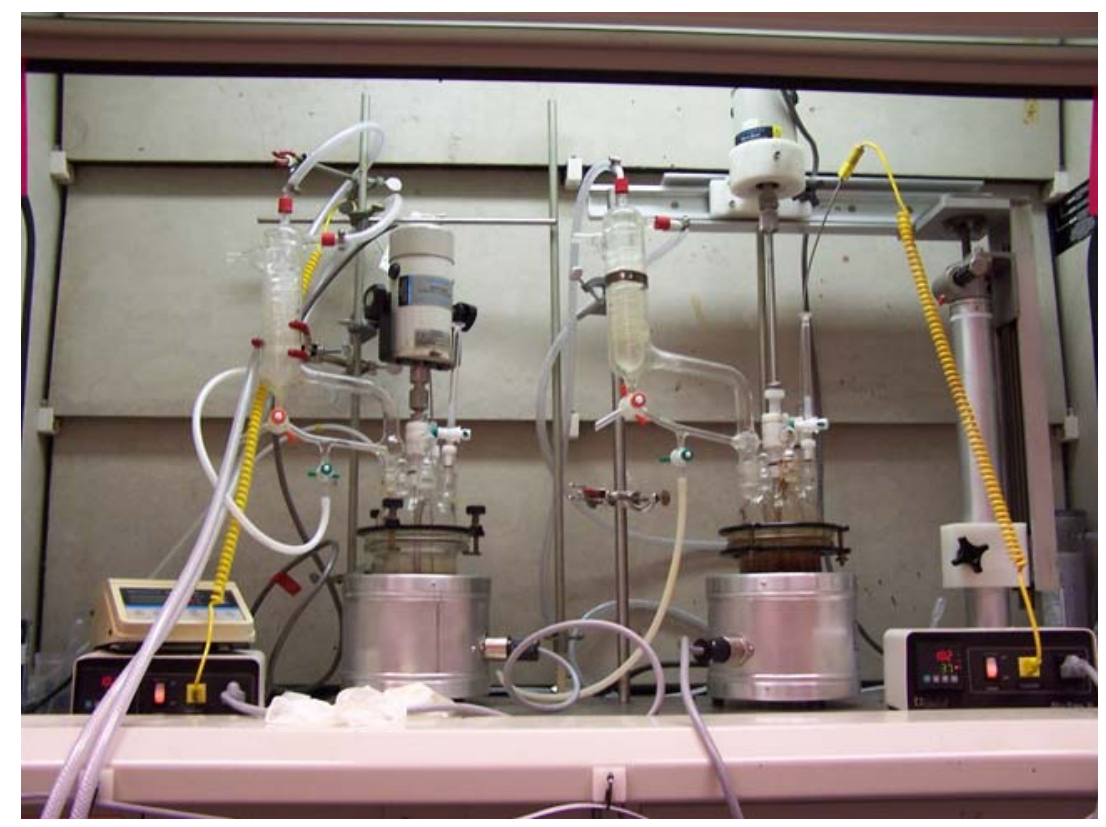

Figure 1. Picture of low and high $\mathrm{pH}$ apparatuses. 


\subsection{PROCEDURE}

A $276 \mathrm{~g}$ mixture of $50 \mathrm{wt} \%$ Frit 418 in water was added to the SRAT products to produce the SME slurry simulants and to achieve a waste loading of $35 \mathrm{wt} \%$. The original SRAT product had a $\mathrm{pH}$ of 4.4; addition of the frit-water mixture increased the $\mathrm{pH}$ somewhat and the slurry $\mathrm{pH}$ was adjusted to the desired levels of 7.5 and 10 by addition of $50 \mathrm{wt} \% \mathrm{NaOH}$. The temperature at boiling was $102^{\circ} \mathrm{C}$, air purge flow rate was $100 \mathrm{~mL} / \mathrm{min}$, the cooling water temperature was $10^{\circ} \mathrm{C}$, and the boil-up rate was $0.7 \mathrm{~g} / \mathrm{min}$.

The mixing speed was originally set at $260 \mathrm{rpm}$ for both tests to obtain a slight vortex, which indicated adequate mixing; however, the HIP slurry thickened immediately after addition of $\mathrm{NaOH}$ and visual inspection of this mixing vortex required a speed of $360 \mathrm{rpm}$. After 30 minutes of boiling, $500 \mathrm{ppm}$ antifoam was added to the HIP rig due to the presence of about $10 \mathrm{~cm}$ of foam. This was the only foaming observed during the course of this work. At about the halfway point, 15 hours, a rheology sample was withdrawn and then $\mathrm{pH}$ measurements were performed on each run. The $\mathrm{pH}$ values decreased to 6.15 and 7.84 for the LOP and HIP runs, respectively; this is significantly lower than the initial values, 7.5 and 10, respectively. This change could have occurred due to precipitation of $\mathrm{Mg}, \mathrm{Mn}$, or other species, which can consume hydroxide anion and thus decrease $\mathrm{pH}$ (see section 4.2.1). This dependence of the supernate concentrations of some metal species with $\mathrm{pH}$ has been observed before in real waste. ${ }^{9}$ A $50 \%$ solution of $\mathrm{NaOH}$ was added again to obtain the desired $\mathrm{pH}$ values. Some $\mathrm{pH}$ drift, albeit less, was also observed after 20 hours of boiling; no further $\mathrm{pH}$ observations were done.

On average, five hours of boiling was performed per day for six days so that the 30 hour cumulative time was satisfied for each. The degree of leaching in the supernate was monitored by using the Process Science Analytical Laboratory (PSAL) Inductively Coupled Plasma-Atomic Emission Spectrometer (ICP-AES) to determine the elemental supernate concentrations of $\mathrm{B}, \mathrm{Li}$, and $\mathrm{Si}$ which are the principal elements that exist in Frit 418 but are not present in the sludge. With one exception, a sample was withdrawn at the end of each day and later subjected to elemental analysis. The experiments were run under conditions of reflux for the first 25 of the total 30 hours and the remaining time was used to remove water to obtain a target of $45 \%$ total solids content. The rheology was measured after 15 hours and after 30 hours of boiling with a RS-600 rheometer using a concentric cylinder geometry. The flow elements consisted of a 5 minute ramp up to $300 \mathrm{~s}^{-1}$ shear rate, a 1 minute hold, and a 5 minute ramp down to zero shear rate.

XRD measurements were performed with a Bruker D8 X-ray diffractometer $(\mathrm{Cu} \mathrm{K \alpha}, 1.54 \AA)$. Step scanning was performed over the $2 \Theta$ ranges of $5-70^{\circ}$ with a step size of $0.02^{\circ}$ and a dwell time of 1 s. A NaI scintillation detector was used. Search-match identification was performed with Jade software version 8.5 from Materials Data Inc. Samples were prepared by using a filter to remove the supernate.

In addition to the sludge experiments, a blank test was run without the presence of SB5-6; i.e., only Frit 418 and water were used. A mixture of $2000 \mathrm{~g}$ of water and $1077 \mathrm{~g}$ of Frit 418 was added to the apparatus and two runs, at the same $\mathrm{pHs}$, were performed separately. The 
apparatus was the same as that used for the sludge experiments except that a high temperature $\mathrm{pH}$ probe was used to perform the measurements in situ. Boiling was performed for only seven hours and hot samples were withdrawn every hour for elemental analysis. Rheology measurements were not possible because of the lower viscosity of the frit-water mixture. It is important to note that immediately upon the addition of frit to water, the $\mathrm{pH}$ increased to about 10. This is due to the well known reactions of metal oxides with water to form hydroxides. ${ }^{10}$ Thus, the LOP frit-water run required the addition of acid $\left(\mathrm{HNO}_{3}\right.$ was used) to lower the $\mathrm{pH}$ down to 7.5. 


\subsection{RESULTS}

\subsection{RHEOLOGY MEASUREMENTS}

Rheology measurements were performed at the halfway point and at the end of the experiments, see Figures 2 and 3. Water was removed from both runs in the last five hours of boiling to ensure the $45 \%$ total solids content target was achieved; these were measured with a moisture analyzer. Thus, comparisons can be made between LOP and HIP runs at each time, but comparisons cannot be made between the 15 hour and 30 hour measurements since the total solids compositions were different. Because of the irregularity and uncertainties exhibited by the rheograms, calculations of the consistencies and yield stresses are not very meaningful. The reason for the irregularities of the low $\mathrm{pH}$ rheograms is uncertain. While the spike in Figure 2 can be explained as a frit particle being stuck for a short time between the concentric cylinders of the rheometer, the unusual, overall shapes of the rheograms indicate a separation of particles due to the thinness of the slurry in an accelerated system (centrifugal force due to the rotation of the inner cylinder).

Nonetheless, it is clear that the high $\mathrm{pH}$ slurry is thicker and has a greater yield stress (yintercept). This is consistent with the need to operate at a higher mixing speed, as noted above. Moreover, it seems that boiling time did not contribute to the thickening since there is little variation between the 15 hour and 30 hour samples in the caustic run. It is more likely that the $\mathrm{pH}$ has a greater influence on the rheology than the boiling time.

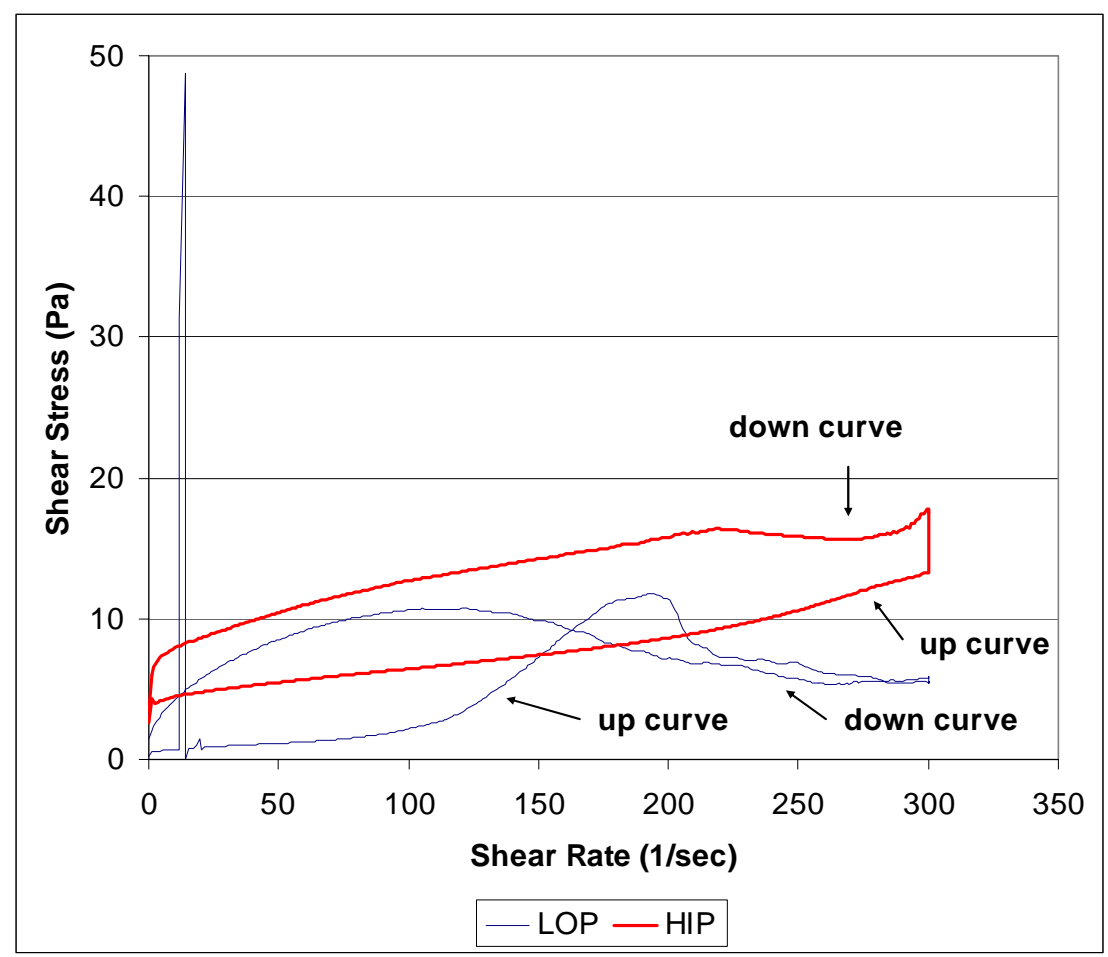

Figure 2. Rheograms of both low and high pH slurries after 15 hours of boiling. 


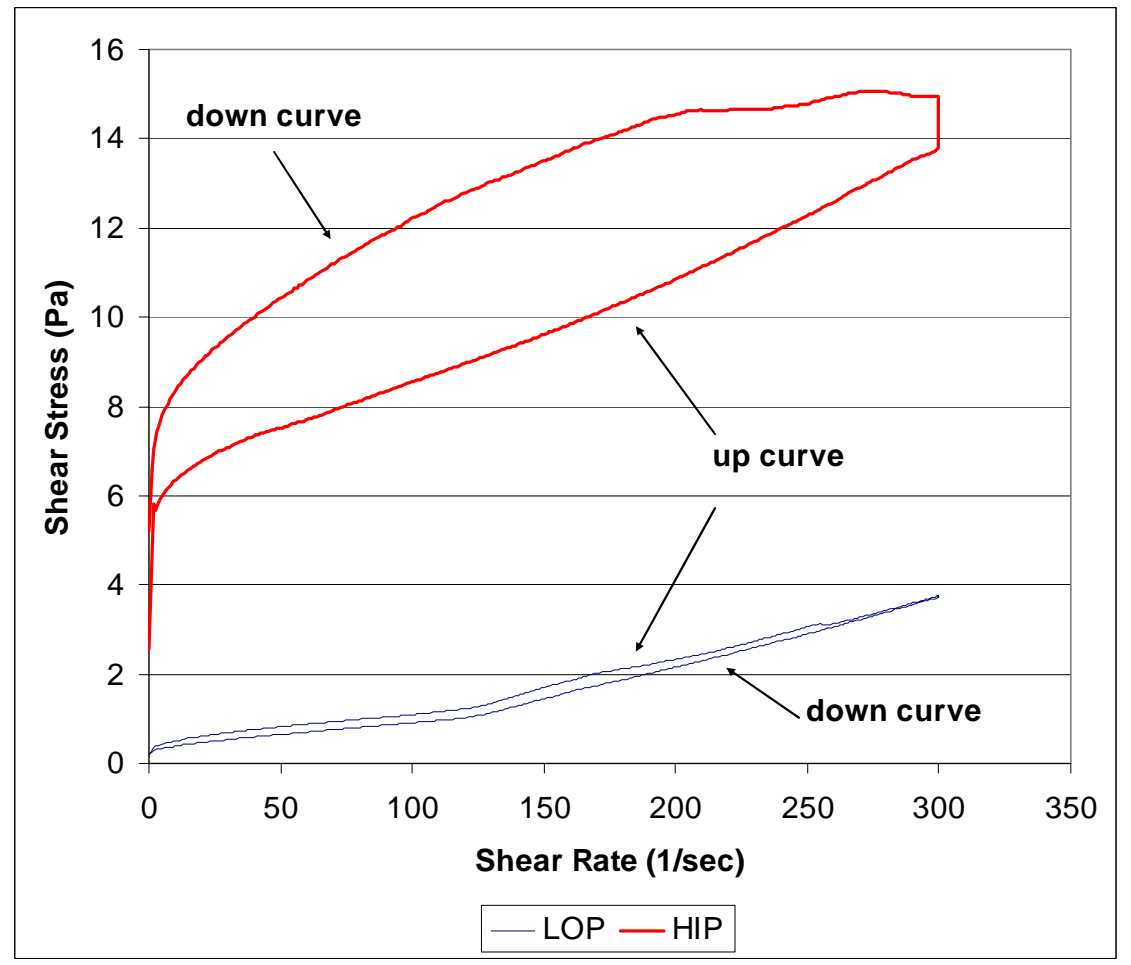

Figure 3. Rheograms of both low and high pH slurries after 30 hours of boiling.

\subsection{ELEMENTAL ANALYSES}

\subsubsection{SB5-Frit 418 Study}

ICP-AES was used to determine the amount of leaching by measuring the supernate concentrations of $\mathrm{B}, \mathrm{Li}$, and $\mathrm{Si}$ which are the principal elements that exist in Frit 418 but are not present in the sludge. The composition ${ }^{11,12}$ of Frit 418 is shown in Table 2. Supernate samples were withdrawn and measured on five of the six separate days of boiling, including the final result. Using the composition of Frit 418, the concentrations of the contaminants (from leaching) in the supernate, and assuming that all of the $\mathrm{B}$ and $\mathrm{Li}$ partitioned into the supernate (since we do not know how much could have partitioned into the non-frit, solid phase), lower limit leaching percentages were calculated for the final sample after 30 hours of boiling, see Table 3. These percentages refer to the fraction of the mass of each leached element in the supernate divided by the total mass of the element in the added frit. The Si percentages are not included because a significant amount of $\mathrm{Si}$, about $2 \%$ on a calcined solids basis, was added as part of the original SB5-6 recipe.

Table 2. Composition of Frit 418, wt\%.

\begin{tabular}{|c|c|c|c|}
\hline $\mathbf{B}_{\mathbf{2}} \mathbf{O}_{\mathbf{3}}$ & $\mathbf{L i}_{\mathbf{2}} \mathbf{O}$ & $\mathbf{N a}_{2} \mathbf{O}$ & $\mathbf{S i O}_{\mathbf{2}}$ \\
\hline 8 & 8 & 8 & 76 \\
\hline
\end{tabular}


Table 3. Calculated lower limit of leaching percentages (mass) of $\mathrm{B}$ and $\mathrm{Li}$.

\begin{tabular}{|c|c|c|}
\hline $\mathbf{p H}$ & $\mathbf{B}$ & $\mathbf{L i}$ \\
\hline LOP & $2.3 \%$ & $4.7 \%$ \\
\hline HIP & $0.13 \%$ & $1.1 \%$ \\
\hline
\end{tabular}

Figure 4 shows a semi-log plot of the lower limit leaching percentages of these elements as a function of time. As expected, the low and high $\mathrm{pH}$ runs exhibit an increase of leachate concentrations with time, especially for $\mathrm{B}$ and $\mathrm{Li}$. However, it is the lower $\mathrm{pH}$ run that shows a significantly greater amount of leaching, about an order of magnitude greater by the end of the experiments; i.e., there is an inverse proportion between $\mathrm{pH}$ and leaching in the sludge runs. Overall, the results indicate that leaching increased as a function of time, is greatest for $\mathrm{Li}$, and has an inverse proportion with $\mathrm{pH}$.

As indicated in the Procedure section, when frit is brought into contact with water, alkali hydroxides are formed, ${ }^{9}$

$$
\mathrm{M}_{2} \mathrm{O}+\mathrm{H}_{2} \mathrm{O} \rightarrow 2 \mathrm{MOH}
$$

This accounts for the leaching of $\mathrm{Li}$ and $\mathrm{Na}$. Boron oxide reacts to produce boric acid, ${ }^{13,14}$

$$
\begin{aligned}
& \mathrm{B}_{2} \mathrm{O}_{3}+\mathrm{H}_{2} \mathrm{O} \rightarrow \mathrm{H}_{3} \mathrm{BO}_{3}\left(\text { or } \mathrm{B}(\mathrm{OH})_{3}\right)+\text { products } \\
& \mathrm{B}(\mathrm{OH})_{3}+2 \mathrm{H}_{2} \mathrm{O} \rightarrow\left[\mathrm{B}(\mathrm{OH})_{4}\right]^{-}+\mathrm{H}_{3} \mathrm{O}^{+}
\end{aligned}
$$

$\mathrm{SiO}_{2}$, the major component of the frit, reacts in caustic medium and exhibits a strong dependence on hydroxide anion concentration, ${ }^{15-17}$

$$
\mathrm{SiO}_{2}+4 \mathrm{OH}^{-} \rightarrow \text { products }
$$

From Figure 4, it is clear that Li leaching, equation (1), is faster than that of B, equation (2). At low $\mathrm{pH}$, the difference is fairly small and may be due to either a preferential attack by water on the $\mathrm{Li}$ or due to a difference in products - $\mathrm{Li}$ becomes quickly solvated while the boron oxide undergoes various steps to produce a weak acid. At high $\mathrm{pH}$ the $\mathrm{B}$ concentration is considerably lower. A likely explanation is that $\mathrm{B}_{2} \mathrm{O}_{3}$ can undergo adsorption ${ }^{18}$ onto $\mathrm{Mg}(\mathrm{OH})_{2}$ particles; at high $\mathrm{pH}$ levels, this insoluble precipitate is likely to be present as discussed below. 
SRNL-STI-2009-00751, REVISION 0

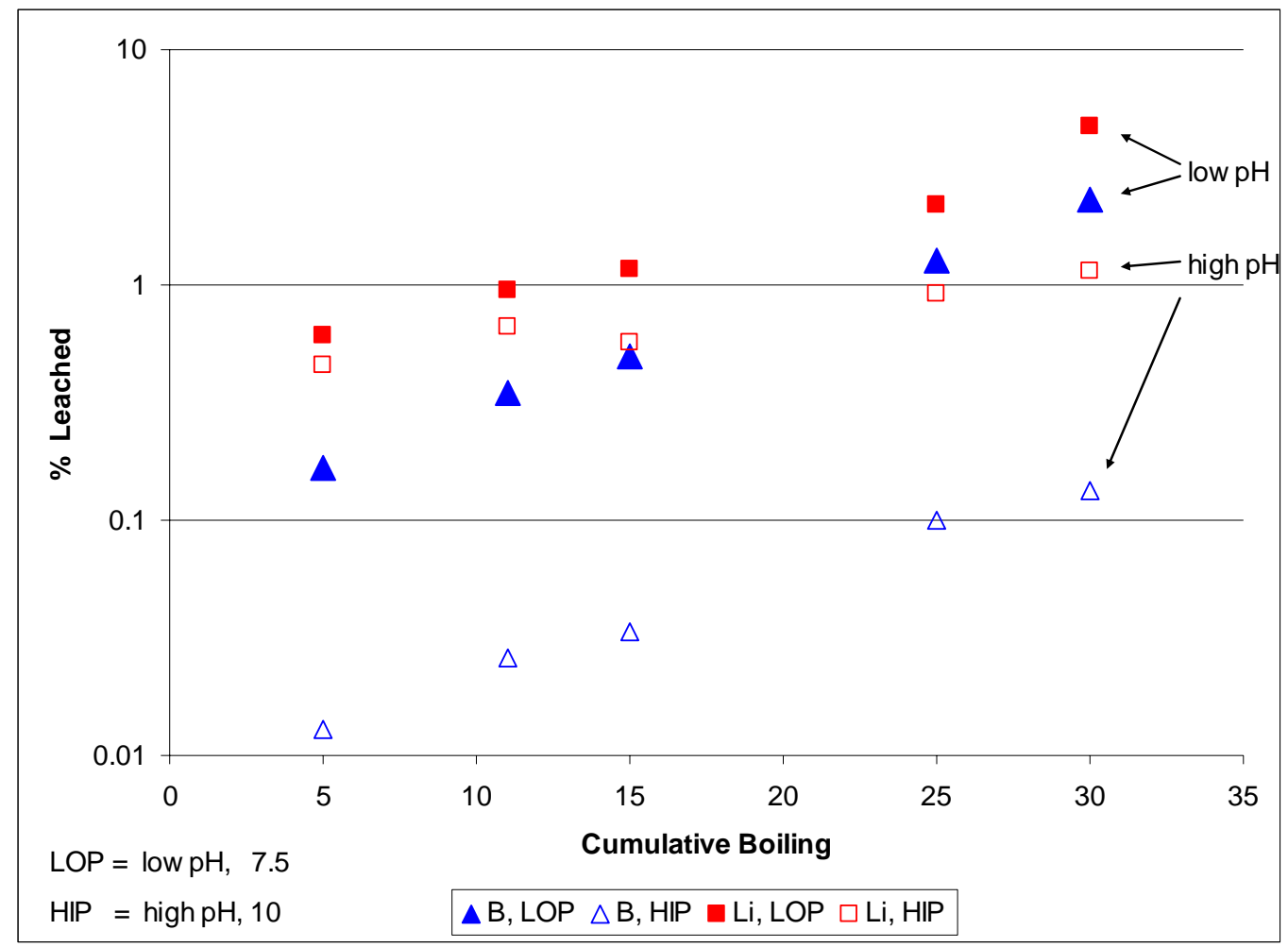

Figure 4. Lower limit leaching \% of $\mathrm{B}, \mathrm{Li}$, and $\mathrm{Si}$ as a function of time and $\mathrm{pH}$.

The supernate concentrations of sludge (not from frit) elements $\mathrm{Mg}$ and $\mathrm{Mn}$ decreased by about 1.5 and 3 orders of magnitude, respectively, in the high $\mathrm{pH}$ run, see Figure 5; the low $\mathrm{pH}$ run exhibited little variation. The reason for the increase of elemental concentrations at the end of boiling in the low $\mathrm{pH}$ run is not understood since a concentration correction was already applied; the target solids content, $45 \mathrm{wt} \%$, was accomplished by removing water in the last five hours of the experiment.

The initial $\mathrm{Mg}$ and $\mathrm{Mn}$ concentrations are plotted, Figure 5, at -2 hours; this negative time value is used because no sample was withdrawn at the beginning of boiling. Instead these are dilution-corrected (addition of water and frit) supernate concentrations of $\mathrm{Mg}$ and $\mathrm{Mn}$ in the original SB5-6 SRAT product. By plotting these initial values, two effects can be deconvoluted: preparation and boiling time. The former refers to the steps used to prepare the slurry: a) addition of water, b) addition of frit, c) heating to boil, and d) adjustment of $\mathrm{pH}$ (addition of $\mathrm{NaOH}$ ) at the beginning of boiling. The plot shows that the precipitation occurred only in the high $\mathrm{pH}$ run during two occasions, sometime near the beginning of the run and after the 15 hour sample. These three constraints correspond to adjustment of $\mathrm{pH}$ to caustic levels, once at the beginning of boiling and once after 15 hours of boiling. Thus, it can be concluded that these drops in concentration are likely due to the adjustment of $\mathrm{pH}$ (addition of $\mathrm{NaOH}$ ) and not boiling time. Unfortunately, no samples were withdrawn just before and just after the adjustment of $\mathrm{pH}$ at the beginning of boiling. 


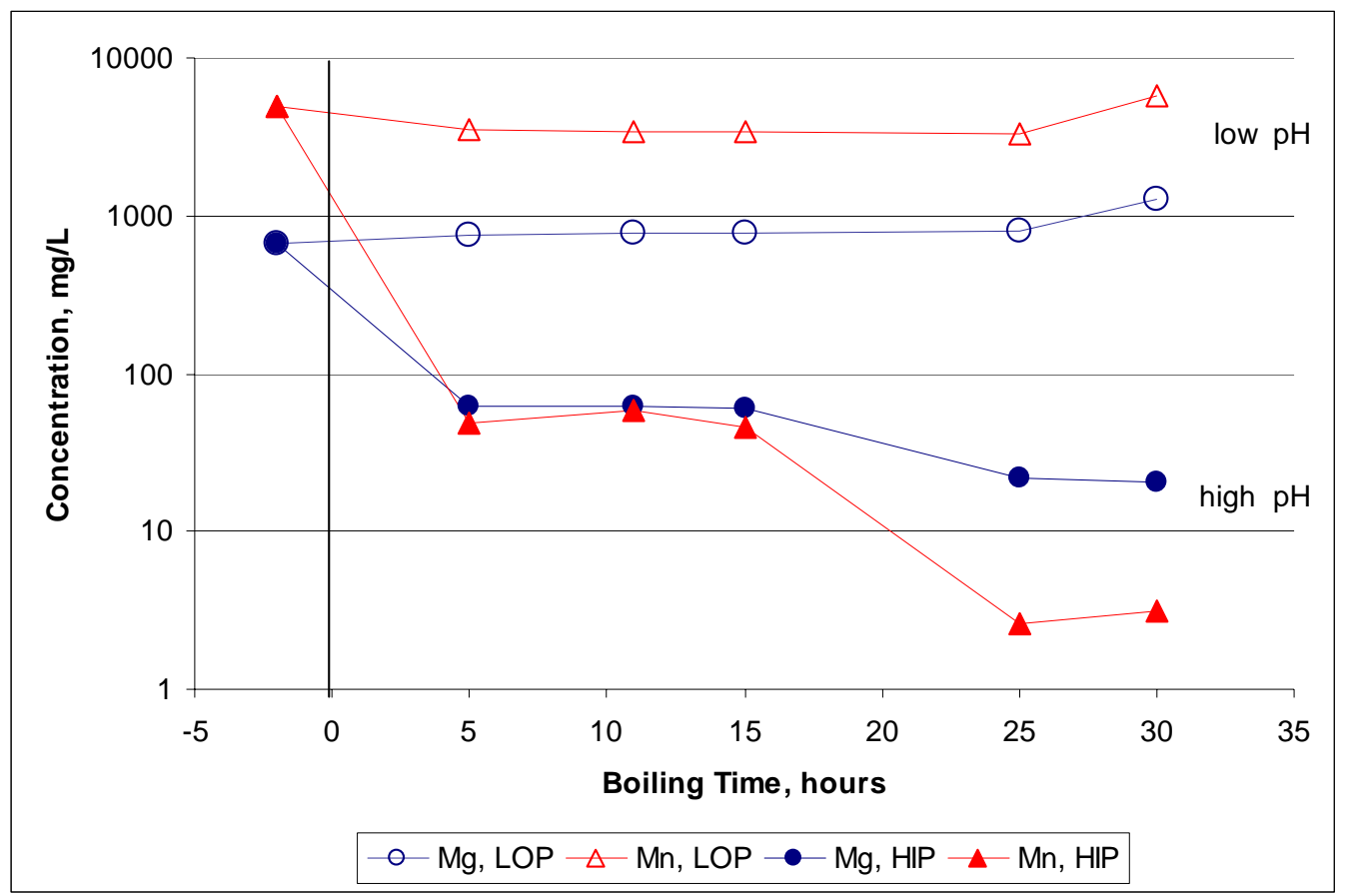

Figure 5. Concentration of several elements as a function of time.

The identities of the precipitates are most likely insoluble $\mathrm{Mg}(\mathrm{OH})_{2}$ and $\mathrm{Mn}(\mathrm{OH})_{2}$. Using the literature values of the solubility product constants at $25^{\circ} \mathrm{C}$ of $\mathrm{Mg}(\mathrm{OH})_{2}$ and $\mathrm{Mn}(\mathrm{OH})_{2}, 5.61 \times$ $10^{-12}$ and $1.60 \times 10^{-13}$, respectively, ${ }^{19,20}$ and adjusting the values for the temperature, yields a ratio $^{21}$ of the equilibrium concentrations of $\mathrm{Mg}$ to $\mathrm{Mn}$ of 19 , while the observed ratio in this high $\mathrm{pH}$ run after 25 hours of boiling is 17 . This agreement indicates that caustic conditions effect the precipitation of hydroxides of $\mathrm{Mg}$ and $\mathrm{Mn}$. Finally, since these metals account for about five weight percent of the original sludge composition (most of $\mathrm{Mg}$ and $\mathrm{Mn}$ were in supernate, $74 \%$ and $94 \%$, respectively) and because these underwent a considerable amount of precipitation, it is likely that this increase in insoluble solids could be sufficient to explain the increase in thickness at high $\mathrm{pH}$. Note the lack of precipitation in the low $\mathrm{pH}$ run and the corresponding lack of thickening. Thus, it appears that precipitation or increase of insoluble solids is correlated with thickening.

The measurements also demonstrate that the concentrations of the following elements, also not present in the frit, $\mathrm{Ba}, \mathrm{Ca}, \mathrm{K}$, and $\mathrm{S}$, did not vary with time as much as the $\mathrm{Mg}$ and $\mathrm{Mn}$ for both runs; these are tabulated in Appendix A. Of these elements, Ca precipitated to an appreciable degree, possibly due to formation of calcium carbonate.

\subsubsection{Frit 418-Water Blank Study}

To separate the effects of the frit from that of the sludge, a blank test was run without sludge. Figure 6 shows the lower limit percent leaching in the frit-water experiment. Note that $\mathrm{Na}$ is 
not included in the analysis because of its presence in the sludge. Again, as expected, the leaching increases with time and $\mathrm{Li}$ is leached more quickly than $\mathrm{B}$. Unlike the sludge system, here we observe that high $\mathrm{pH}$ leads to greater leaching. This is not surprising since semiconductor studies show that $\mathrm{SiO}_{2}$ is etched more quickly under caustic conditions, such as in aqueous solutions of $\mathrm{KOH} .{ }^{15-17}$ And since $\mathrm{SiO}_{2}$ quickly reacts and since it is the major component at $71 \mathrm{~mole} \%$, the leaching rates of the $\mathrm{B}$ and $\mathrm{Li}$ should also be greater and should be similar to the former. This is confirmed by inspection of Figure 6 where the leaching levels of $\mathrm{Si}, \mathrm{B}$, and $\mathrm{Li}$ at high $\mathrm{pH}$ are indistinguishable after about 2 hours of boiling.

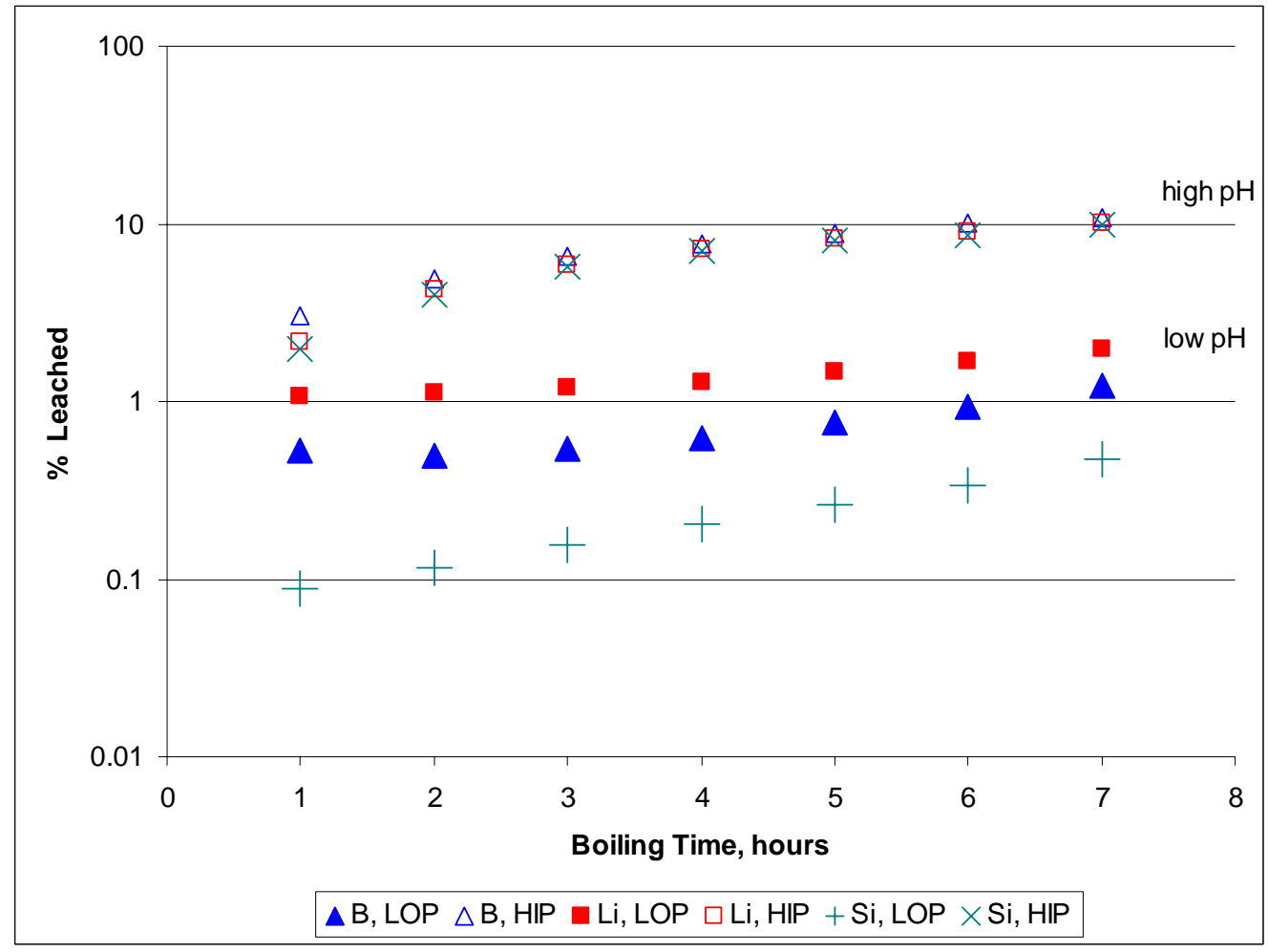

Figure 6. Lower limit leaching \% as a function of time and $\mathrm{pH}$ in Frit-water system.

\subsubsection{Comparison of Both Systems}

In order to compare the sludge and frit-water leaching \% results, a combined plot, including the $\mathrm{Si}$ concentrations, is shown in Figure 7 and the calculated values are tabulated in Appendix B. The concentrations, used to calculate leaching \%, are tabulated in Appendix C. The time axis is limited to 15 hours for clarity. The leaching in the frit-water system varies from a factor of two to almost three orders of magnitude greater (depending on conditions and species) than the sludge system even though the boiling time of the former is less than a fourth. A possible reason is a smaller driving force or greater ionic strength in the sludge system. Another possibility for the greater leaching in the frit-water system is the absence of a physical effect, coating of frit particles by sludge; i.e., the sludge coating could inhibit mass 
transfer and thus slow the leaching processes, equations (1) - (3). This effect could account for the observed lower leach rate of $\mathrm{Si}$ in the sludge system at high $\mathrm{pH}$, despite the high concentration of $\mathrm{OH}^{-}$which, according to equation (3), would increase the leach rate.

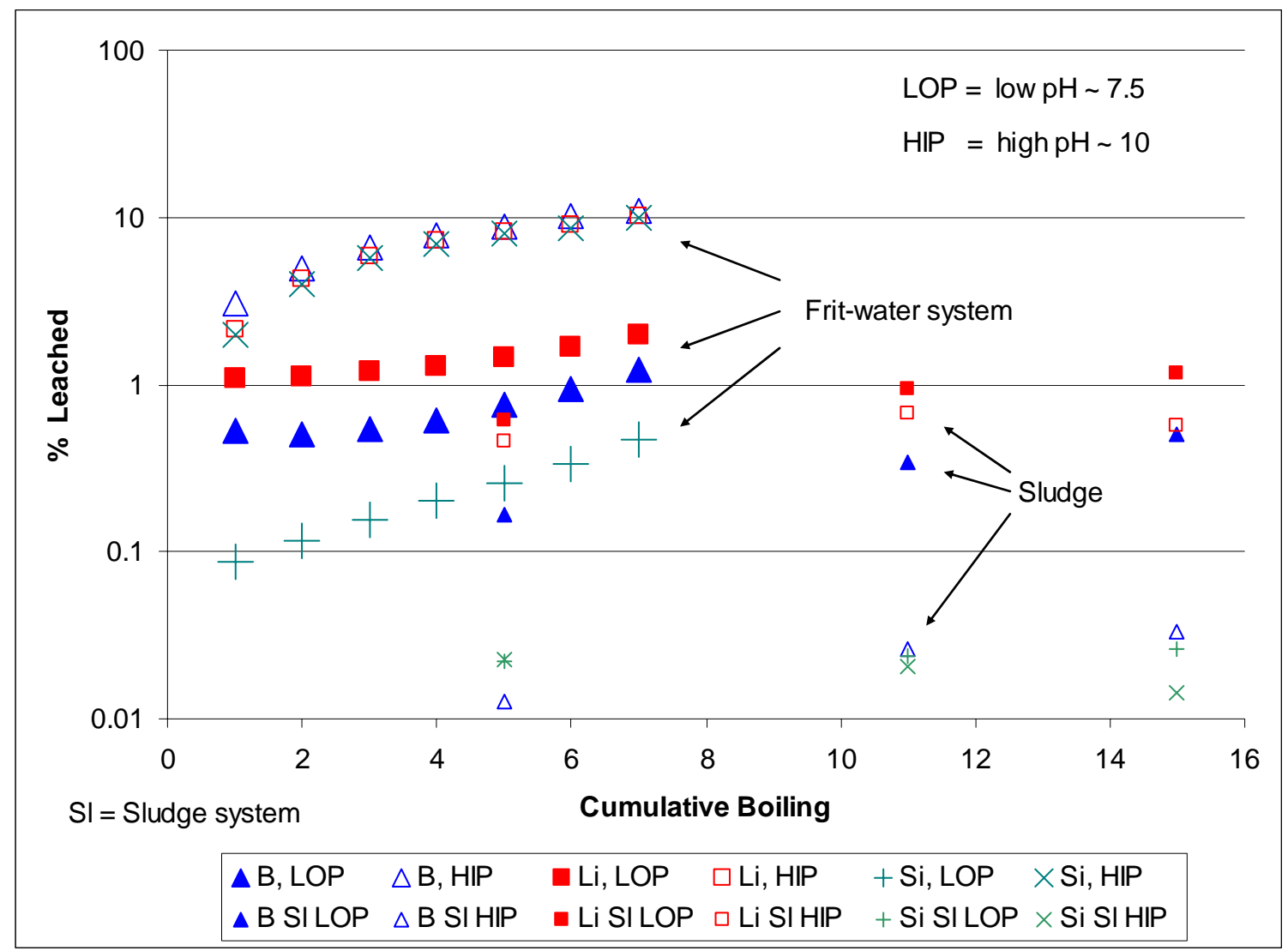

Figure 7. Lower limit leaching \% of sludge (smaller symbols) and Frit-water systems.

The greatest differences between the two systems, Figure 7, are the amounts of $\mathrm{Si}$ and $\mathrm{B}$ leached at high $\mathrm{pH}$, almost three orders of magnitude variation. The frit water system is simpler and its behavior is easier to explain. At low $\mathrm{pH}$, this system exhibits considerable leaching of the elements with $\mathrm{Li}$ being dominant. The B leaching is somewhat slower, perhaps for the same reasons as in the sludge system, possibly due to preferential attack of water on alkali oxide or, since boric acid is a weak acid, the final reaction may be a reversible equilibrium step. Leaching of silica is much slower because of the relatively low hydroxide anion concentration, equation (3). At high $\mathrm{pH}$, the $\mathrm{OH}^{-}$concentration is high and leaching of silica dominates. And since $\mathrm{SiO}_{2}$ is the main component of the frit at $71 \mathrm{~mole} \%$, the other components closely match the silica leaching rate.

The sludge system behaves differently. Like the frit-water system, at low $\mathrm{pH}$ the dominant leaching mechanism is via hydration of the metal oxide, such as Li. Again, the B is leached somewhat more slowly, possibly for reasons given above. The silica leaching is very low due to the low $\mathrm{OH}^{-}$concentration. At high $\mathrm{pH}$, however, the sludge system shows a considerable 
decrease in B leaching and, surprisingly, the silica leaching remains essentially the same at low values; the silica leaching is not increased dramatically at higher $\mathrm{OH}^{-}$concentrations in the sludge system. As stated above, the decrease of B concentration in the supernate is likely due to adsorption onto particles of $\mathrm{Mg}(\mathrm{OH})_{2}$, which were precipitated under caustic conditions. The low supernate concentration of Si may be due to a similar effect, adsorption of sludge particles onto the frit, which could increase the mass transfer resistance to transport of $\mathrm{OH}^{-}$to the silica on the frit surface. That is, in the sludge system a coating could form to slow the $\mathrm{OH}^{-}$reaction with the silica but the water, which is neutral and at much higher concentration, likely encounters less mass transfer resistance and thus allows for a faster leaching of Li.

\subsection{XRD MEASUREMENTS}

Finally, X-ray Diffraction (XRD) analyses were performed to determine whether sodium aluminosilicate crystals were present in the solid phase. Inspection of the XRD spectra in Figures 8 and 9 indicate the presence of $\mathrm{SiO}_{2}$ crystals (quartz) and $\mathrm{Al}(\mathrm{OH})_{3}$ crystals (bayerite, quartz, gibbsite, and nordstrandite) in both runs, but no sodium aluminosilicate was observed. Thus, while there is no evidence that crystalline sodium aluminosilicate is present, the observation of the broad continua in the XRD spectrum indicates a considerable amount of amorphous solid which could contain undetectable sodium aluminosilicate, ${ }^{22,23}$ thus, its contribution to thickening cannot be ruled out.

XRD does not reveal the presence of $\mathrm{Mg}(\mathrm{OH})_{2}$ or $\mathrm{Mn}(\mathrm{OH})_{2}$ in the solid phase even though the PSAL measurements of the supernate indicated considerable precipitation, on the order of several weight percent, which is just above the XRD detection limit. There are several possible reasons for this discrepancy. The precipitate could have been formed in the amorphous state. It is also possible that the stronger $\mathrm{Al}$ and $\mathrm{Si}$ signals could obscure weak hydroxide peaks. Thirdly, $\mathrm{B}_{2} \mathrm{O}_{3}$ could block detection by coating the $\mathrm{Mg}(\mathrm{OH})_{2}$ (and possibly $\mathrm{Mn}(\mathrm{OH})_{2}$ ) particles, see section 4.2.1. A fourth possibility is that the hydroxide particle sizes could be smaller than the detection limit of XRD; for example, nanoscale crystallites of magnesium hydroxide have been produced hydrothermally. ${ }^{24}$ 


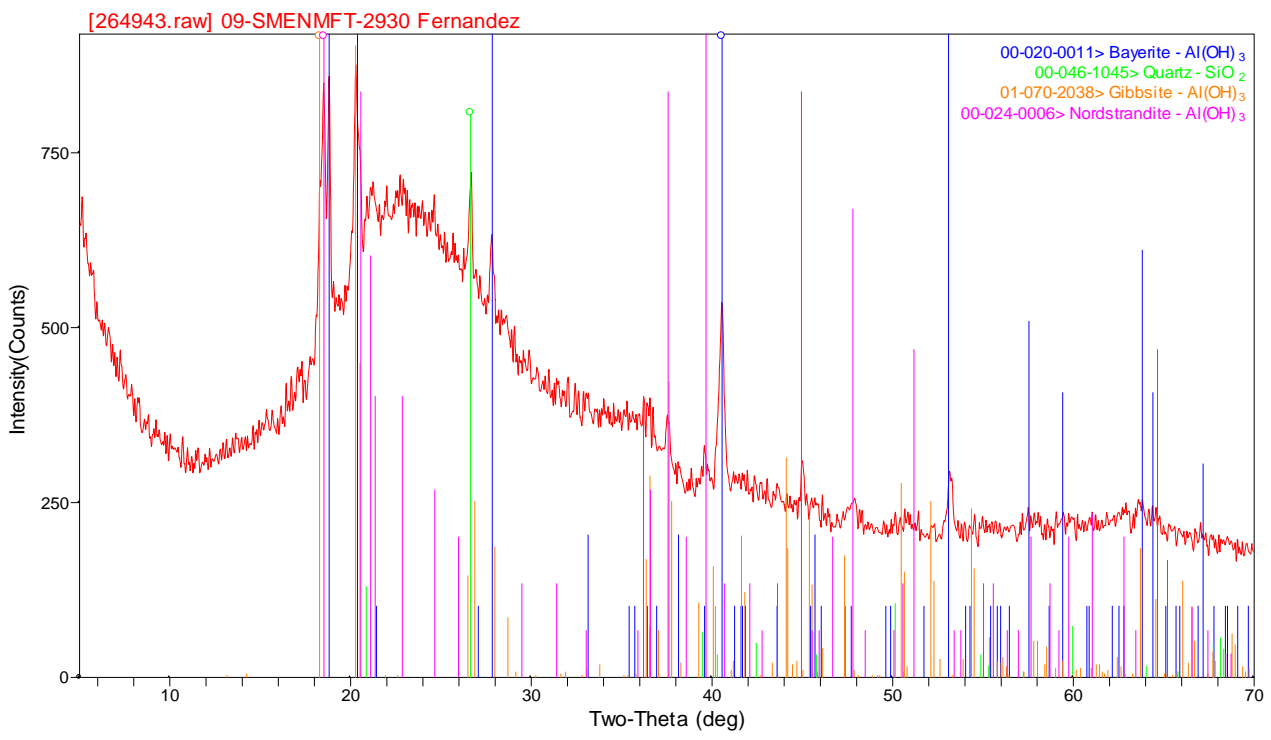

Figure 8. XRD measurements of the low pH solids.

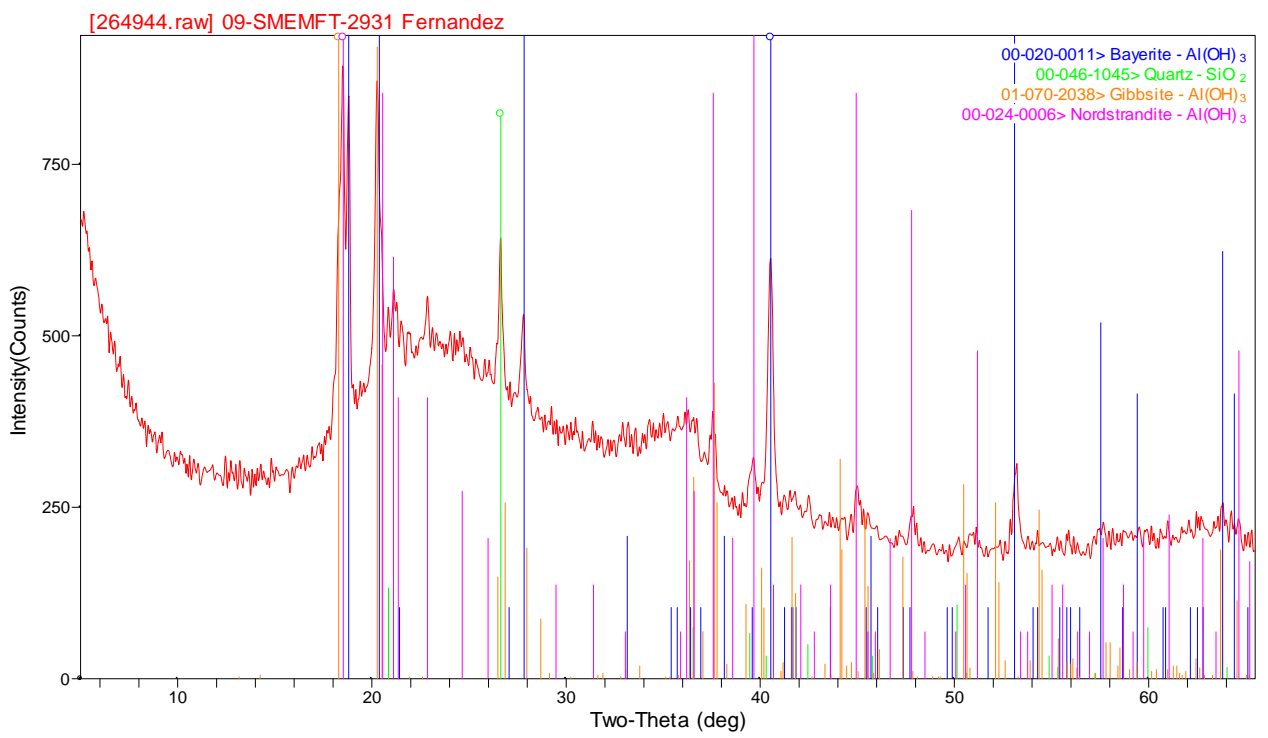

Figure 9. XRD measurements of the high pH solids. 
SRNL-STI-2009-00751, REVISION 0

\subsection{CONCLUSIONS}

It was expected that thickening and gel formation could occur when non-acidic or alkaline conditions are encountered in a) glass frit-water mixtures and b) the MFT feed loop. Since the XRD measurements did not detect sodium aluminosilicate in crystal form in both low and high $\mathrm{pH}$ slurries, it is unlikely that gel formation via this crystal occurs in SB5 simulant SME processes over a wide range of $\mathrm{pH}$ values.

The observations imply that subjecting SB5 simulant sludge to caustic conditions, such as those found in a SB5 SME cycle (reflux boiling), will cause a measurable increase in thickness (relative to neutral or acidic conditions) but that this is not due to crystalline sodium aluminosilicate-mediated gel formation since none was detected by XRD in both the low and high $\mathrm{pH}$ runs. However, amorphous sodium aluminosilicate could have been present. Because of the absence of sodium aluminosilicate and in light of the elemental composition, rheology, and thermochemistry, it is likely that the precipitation of the insoluble hydroxides of $\mathrm{Mg}$ and $\mathrm{Mn}$, observed under caustic conditions, contributes to the thickening of the SB5-6 slurry.

Leaching consists of the formation of metal hydroxides from the oxides, the formation of boric acid from the boron oxide, and dissolution of silica. It was not expected that an increase in $\mathrm{pH}$ would lead to a decrease in leaching in the SB5 simulant system. Thus, a blank study, consisting of only Frit 418 and water was conducted to gain further insight. The opposite behavior was seen in the frit-water system, an increase in $\mathrm{pH}$ leads to an increase in leaching; this behavior is not surprising as silica dissolution by hydroxide anion has been well established in the semiconductor literature. The measurements also revealed greater leaching of $\mathrm{B}, \mathrm{Li}$, and $\mathrm{Si}$ elements from a factor of two to almost three orders of magnitude relative to the sludge runs. Two possible reasons why the sludge system exhibits less leaching are: a) a higher ionic strength would provide a smaller driving force to leach and $b$ ) the presence of sludge coating on the frit particles would increase mass transfer resistance. More specific comparisons of both systems show that the B leaching shows a negative correlation with $\mathrm{pH}$ level in the sludge, unlike the frit-water system. This is likely due to the removal of B by adsorption onto $\mathrm{Mg}(\mathrm{OH})_{2}$.

Because the increase in thickness was modest in the caustic case, likely due to precipitation of the insoluble hydroxides of $\mathrm{Mg}$ and $\mathrm{Mn}$, the cause of the clogs in the DWPF melter feed loop is still unknown. An alternative explanation is that the SB5 waste, like the simulant used in this study, is too thin and that this could contribute to a loss of two-phase flow which could cause plugging of a restricted and poorly mixed zone like the melter feed loop. ${ }^{25}$ This is feasible: a slurry can exhibit increasing flow resistance at lower flow rates. ${ }^{26}$

Future work could include a study of a SB5 SME product's flow behavior as a function of $\mathrm{pH}$ level and flow rate. The observations could help determine whether a thin slurry could separate into liquid and solid phases and cause a clog in a constricted and poorly-mixed zone such as in a pipe or near a valve. 


\subsection{REFERENCES}

1. Wilmarth, W.R.; Dukes, V.H.; Mills, J.T.; Edwards, T.B., Results of Aluminosilicate Formation Testing, WSRC-TR-2001-00330, Westinghouse Savannah River Company, Aiken, SC 29808 (2001).

2. Reboul, S.H.; Stone, M.E.; Pareizs, J.M; Herman, C.C., Sludge Batch 5 Melter Feed Rheology Study, SRNL-RP-2009-01199, SRNL, Aiken, SC, 29808 (September 2009).

3. Bricker, J.M., Sludge Batch 5 Melter Feed Rheology Study, HLW-DWPF-TTR-2009-0030, SRNL, Aiken, SC, 29808 (August 2009).

4. Fernandez, A. and Stone, M.E., R\&D Directions for SME-MFT Mixing Study, SRNLL3100-2009-00247, SRNL, Aiken, SC, 29808 (September 2009).

5. Fernandez, A. and Stone, M.E., R\&D Directions for SME -MFT Frit-Water Study, SRNLL3100-2009-302, SRNL, Aiken, SC, 29808 (November 2009).

6. Miller, D.H.; Fox, K.M; Pickenheim, B.R.; Stone, M.E., Melt Rate Furnace Testing for Sludge Batch 5 Frit Optimization, SRNL-STI-2008-00092, SRNL, Aiken, SC, 29808 (September 2008).

7. Prestbo, E.; Garcia, J.; Swartzendruber, P.; von der Geest, E.; Rosencrance, S., Evaluation of the Potential for Chemical Formation of Dimethyl Mercury at High $\mathrm{pH}$ in the Presence of Selected Organics, SRT-LWP-2003-00009, Westinghouse Savannah River Company, Aiken, SC 29808, (January 2003).

8. Manahan, S.E., Environmental Science and Technology, CRC Press, Boca Raton, Florida, p. 173, (1997).

9. Coleman, C.J.; Bibler, N.E.; Ferrara, D.M.; Siegwald, S.F., Reaction of Formic and Nitric Acids with Savannah River Site Radioactive HLW Sludge in the DWPF Pre Treatment Steps, WSRC-MS-93-563, Washington Savannah River Company, Aiken, SC 29808 (March 1994).

10. Sharpe, A.G., Inorganic Chemistry, Longman Group, London, p. 233, (1981).

11. Fox, K.M.; Edwards, T.B; Peeler, D.K.; Best, D.R; Reamer, I.A.; Workman, R.J., High Level Waste (HLW) Sludge Batch 4 (SB4) with Frit 418: Results of a Phase II Variability Study, WSRC-STI-2006-00329, SRNL, Aiken, SC, 29808 (December 2006).

12. Lorier, T.H. and Smith, M.E., Melt Rate Assessment of SB2/3 with Frit 418-Effects of Waste Loading and Acid Addition, WSRC-TR-2004-00098, SRTC, Aiken, SC 29808 (February 2004). 
13. Li, Q.; Xue, F.; Mak, T.C.W., Crystalline Inclusion Compounds of Urea with Oxoboron Components. Stabilization of the Elusive Dihydrogen Borate Anion in a Hydrogen-Bonded Host Lattice, Inorg. Chem., 38(18), 4142-4145, (1999).

14. Cotton, F.A.; Wilkinson, G.; Gaus, P.L., Basic Inorganic Chemistry, $3^{\text {rd }}$ Edition, John Wiley \& Sons, New York, Chapter 12, (1995).

15. Paul, A., Chemistry of Glasses, $2^{\text {nd }}$ Edition, Chapman \& Hall, London, Chapters 6-8, (1990).

16. Charles, R.J., Static Fatigue of Glasses. I, J. Appl. Phys., 19(11), 1549-1543, (1958).

17. Seidel, H.; Csepregi, L.; Heuberger, A.; Baumgärtel, H., Anisotropic Etching of Crystalline Silicon in Alkaline Solutions, J. Electrochem. Soc., 137(11), 3612-3626, (1990).

18. Martinac, V.; Labor, M.; Petric, N., $\mathrm{B}_{2} \mathrm{O}_{3}$ and $\mathrm{CaO}$ in the Magnesium Oxide from Seawater, Materiali in Tehnologije (MTAEC9), 40(2), 65-69, (2006).

19. Fox, R.K.; Swinehart, D.F.;Garrett, A.B., The Equilibria of Manganese Hydroxide, $\mathrm{Mn}(\mathrm{OH})_{2}$, in Solutions of Hydrochloric Acid and Sodium Hydroxide, J. Am. Chem. Soc., 7(63), 1779-1782, (1941).

20. Lide, D.R., CRC Handbook of Chemistry and Physics, $71^{\text {st }}$ Edition, CRC Press, Boca Raton, 8-39, (1990).

21. Freiser, H., Concepts \& Calculations in Analytical Chemistry. A Spreadsheet Approach, CRC Press, Boca Raton, Chapter 6, (1992).

22. Kostanovic, C.; Bosnar, S.; Subotic, B.; Svetlicic, V.; Misic, T.; Drazic, G.; Havancsak, Study of the microstrucutre of amorphous aluminosilicate gel before and after its hydrothermal treatment, Microporous and Mesoporous Materials, 110, 177-185, (2008).

23. Addai-Mensah, J.; Li, J.; Rosencrance, S.; Wilmarth, W., Solubility of Amorphous Sodium Aluminosilicate and Zeolite A Crystals in Caustic and Nitrate/Nitrite-Rich Caustic Aluminate Liquors, J. Chem. Eng., 49, 1682-1687, (2004).

24. Ding, Y.; Zhang, G.; Wu, H.; Hai, B.; Wang, L.; Qian, Y., Nanoscale Magnesium Hydroxide and Magnesium Oxide Powders: Control over Size, Shape, and Structure via Hydrothermal Synthesis, Chemistry of Materials, 13(2), 435-440, (2001).

25. under review: Reboul, S.H.; Stone, M.E., Real Waste Testing of Sludge Batch 5 Melter Feed Rheology, SRNL-STI-2010-00113, Savannah River Nuclear Solutions, (March 2010).

26. M.E. Smith; Stone, M.E.; D.H. Miller, Impact of Spherical Frit Beads on Simulated DWPF Slurries, WSRC-TR-2005-00418, Washington Savannah River Company, Aiken, SC, 29808 (September 2005). 


\section{APPENDIX A. ELEMENTAL CONCENTRATIONS VERSUS TIME}

\section{LOP, $\mathrm{pH}=7.5$}

\begin{tabular}{|c|c|c|c|c|}
\hline Boil time, hr* & [Ba], $\mathbf{~ m g / L ~}$ & [Ca], mg/L & [K], mg/L & [S], mg/L \\
\hline$-2^{* *}$ & 0.25 & 1723 & 255 & 237 \\
\hline 5 & 0.98 & 1860 & 231 & 177 \\
\hline 11 & 0.86 & 1830 & 233 & 241 \\
\hline 15 & 1.25 & 1830 & 236 & 257 \\
\hline 25 & 0.42 & 2050 & 250 & 251 \\
\hline
\end{tabular}

HIP, $\mathbf{p H}=10$

\begin{tabular}{|c|c|c|c|c|}
\hline Boil time, hr* & [Ba], $\mathbf{~ m g / L ~}$ & [Ca], mg/L & [K], mg/L & [S], mg/L \\
\hline$-2 * *$ & 0.25 & 1723 & 255 & 237 \\
\hline 5 & 0.98 & 1055 & 249 & 176 \\
\hline 11 & 0.87 & 990 & 247 & 188 \\
\hline 15 & 1.08 & 747 & 160 & 116 \\
\hline 25 & 0.3 & 647 & 174 & 122 \\
\hline
\end{tabular}

* The values after 30 hours of boiling are misleading, abnormally high due to removal of water.

** The negative time indicates that these supernate concentrations of components are of the original SB5-6 SRAT product sludge at room temperature before the addition of frit and water, and well before the beginning of boiling. 


\section{APPENDIX B. LEACHING \% VERSUS TIME (FIGURE 7)}

SB5-Frit 418 System

\begin{tabular}{|c|c|}
\hline Boiling time, hr & B \\
\hline 5 & 0.167 \\
\hline 11 & 0.346 \\
\hline 15 & 0.500 \\
\hline 25 & 1.270 \\
\hline 30 & 2.321 \\
\hline
\end{tabular}

$$
\text { LOP, } \mathrm{pH} \sim 7.5
$$

SB5-Frit 418 System

HIP, $\mathrm{pH} \sim 10$

\begin{tabular}{|c|c|c|c|}
\hline Boiling time, hr & B & Li & Si \\
\hline 5 & 0.013 & 0.459 & 0.022 \\
\hline 11 & 0.026 & 0.666 & 0.020 \\
\hline 15 & 0.034 & 0.570 & 0.015 \\
\hline 25 & 0.099 & 0.921 & 0.014 \\
\hline 30 & 0.134 & 1.139 & 0.016 \\
\hline
\end{tabular}

\section{Frit 418-Water System $\quad$ LOP, $\mathrm{pH} \sim 7.5$}

\begin{tabular}{|c|c|c|c|}
\hline Boiling time, hr & $\mathbf{B}$ & $\mathbf{L i}$ & $\mathbf{S i}$ \\
\hline 1 & 0.528 & 1.082 & 0.087 \\
\hline 2 & 0.499 & 1.109 & 0.115 \\
\hline 3 & 0.541 & 1.194 & 0.156 \\
\hline 4 & 0.616 & 1.297 & 0.204 \\
\hline 5 & 0.759 & 1.469 & 0.260 \\
\hline 6 & 0.938 & 1.676 & 0.335 \\
\hline 7 & 1.230 & 1.976 & 0.474 \\
\hline
\end{tabular}

Frit 418-Water System $\quad$ HIP, $\mathrm{pH} \sim 10$

\begin{tabular}{|c|c|c|c|}
\hline Boiling time, hr & $\mathbf{B}$ & $\mathbf{L i}$ & $\mathbf{S i}$ \\
\hline 1 & 3.071 & 2.144 & 1.992 \\
\hline 2 & 4.891 & 4.272 & 4.012 \\
\hline 3 & 6.573 & 5.871 & 5.672 \\
\hline 4 & 7.784 & 7.245 & 7.005 \\
\hline 5 & 8.815 & 8.294 & 7.998 \\
\hline 6 & 10.101 & 9.069 & 8.651 \\
\hline 7 & 10.823 & 10.218 & 9.827 \\
\hline
\end{tabular}




\section{APPENDIX C. SUPERNATE CONCENTRATION VERSUS TIME}

SB5-Frit 418 System

$$
\text { LOP, } \mathrm{pH} \sim 7.5
$$

Concentration in units of $\mathrm{mg} / \mathrm{L}$

\begin{tabular}{|c|c|c|c|}
\hline Boiling time, hr & B & Li & Si \\
\hline 5 & 18.7 & 102 & 35.2 \\
\hline 11 & 38.5 & 157 & 38.1 \\
\hline 15 & 55.7 & 195 & 42.2 \\
\hline 25 & 142 & 363 & 45.6 \\
\hline 30 & 282 & 851 & 82.4 \\
\hline
\end{tabular}

SB5-Frit 418 System

$\mathrm{HIP}, \mathrm{pH} \sim 10$

\begin{tabular}{|c|c|c|c|}
\hline Boiling time, hr & B & Li & Si \\
\hline 5 & 1.43 & 76.5 & 35.7 \\
\hline 11 & 2.90 & 111 & 32.5 \\
\hline 15 & 3.74 & 95.0 & 23.1 \\
\hline 25 & 11.1 & 154 & 22.9 \\
\hline 30 & 16.3 & 207 & 28.0 \\
\hline
\end{tabular}

Frit 418-Water System $\quad$ LOP, $\mathrm{pH} \sim 7.5$

\begin{tabular}{|c|c|c|c|}
\hline Boiling time, hr & B & Li & Si \\
\hline 1 & 70.6 & 217 & 167 \\
\hline 2 & 66.8 & 222 & 220 \\
\hline 3 & 72.4 & 239 & 298 \\
\hline 4 & 82.5 & 260 & 391 \\
\hline 5 & 102 & 294 & 497 \\
\hline 6 & 126 & 336 & 642 \\
\hline 7 & 165 & 396 & 907 \\
\hline
\end{tabular}

Frit 418-Water System HIP, $\mathrm{pH} \sim 10$

\begin{tabular}{|c|c|c|c|}
\hline Boiling time, hr & B & Li & Si \\
\hline 1 & 411 & 429 & 3810 \\
\hline 2 & 654 & 855 & 7680 \\
\hline 3 & 879 & 1180 & 10850 \\
\hline 4 & 1040 & 1450 & 13400 \\
\hline 5 & 1180 & 1660 & 15300 \\
\hline 6 & 1350 & 1820 & 16600 \\
\hline 7 & 1450 & 2050 & 18800 \\
\hline
\end{tabular}




\section{Distribution:}

S. L. Marra, 773-A

A. B. Barnes, 999-W

D. A. Crowley, 773-43A

S. D. Fink, 773-A

B. J. Giddings, 786-5A

C. C. Herman, 999-W

F. M. Pennebaker, 773-42A

J. E. Occhipinti, 704-S

D. C. Sherburne, 704-S

R. T. McNew, 704-27S

J. F. Iaukea, 704-30S

J. W. Ray, 704-S

H. B. Shah, 766-H

J. M. Gillam, 766-H

B. A. Hamm, 766-H

D. D. Larsen, 766-H

C. J. Bannochie, 773-42A

D. K. Peeler, 999-W

M. E. Stone, 999-W

A.I. Fernandez, 999-W

D.C. Koopman, 999-W

D.P. Lambert, 999-W

J.D. Newell, 999-W

J.M. Pareizs, 777-42A

B.R. Pickenheim, 999-W

S.H. Reboul, 773-42A

J. M. Bricker, 704-27S

T. L. Fellinger, 704-26S

E. W. Holtzscheiter, 704-15S

M. T. Keefer, 766-H 